theme 5

society

author(s) strand 1

design policies

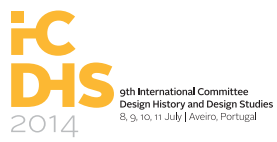

Blucher Design Proceedings Dezembro de 2014, Número 5, Volume 1

Dr. Eleanor Herring e.herring@gsa.ac.uk / ellieherr
Glasgow School of Art, The University of Edinburgh

\title{
Joining the Modern World: A Study of Street Furniture in Postwar Britain.
}

After the Second World War Britain experienced a period of considerable social, political and cultural transition, in which British people witnessed wider access to education, housing and healthcare. British design culture also felt the impact of these changes, in part because design was brought under government control to a far greater degree than ever before. Through legislation like the 1947 Town and Country Planning Act, the establishment of state-funded organizations like the Council of Industrial Design, as well as far greater participation of designers on ministerial committees, the postwar government deliberately sought to introduce 'good design' into people's everyday lives.

Street furniture was just one of many categories of design through which Britain's new social, political and cultural agenda was given physical expression between the early1950 and the late 1960 s. As designed objects within the public realm, street furniture is subject to the input of numerous forces which monitor and regulate that space, and thus give it shape. During this period of transition, government ministries - in consultation with other official organizations, designers and manufacturers - initiated several major street furniture projects. As a result, the design of objects as varied as parking meters, letterboxes, road signage and traffic lights underwent significant change, which altered the face of Britain as a result. But why did the government involve itself with street furniture design at all? Were these projects acts of government-sponsored beautification, or merely part of a wider drive to modernize and upgrade the country's designed environment? More importantly perhaps, given the changes to postwar British society, who was accountable for this process?

Using extensive archival material, government records, contemporary periodicals, newspapers and interviews, this paper will examine these questions and in doing so, expose the complex negotiations that informed the design of street furniture in postwar Britain. It will focus on three examples of street furniture design - the parking meter, road signage and a letterbox - and in doing so, look closely at the British government's design policies between the 1950s-60s, how they were enacted and the conflicts that surfaced as a consequence. By addressing the process by which these objects were reshaped, the paper will reflect on both the state's use of design, and the capacity of design as a way to read political power in society. 


\section{Introduction}

Seen from a distance, postwar Britain was a period characterized by radical transformation. According to historian Arthur Marwick, for most British people this transformation was experienced largely in terms of new opportunities and freedoms, in which individuality, diversity, equality and prosperity sat alongside the establishment of the Welfare State (Marwick, 1991: 67-68). Successive postwar governments sought to give physical expression to the new social, political and cultural agenda. And through the development of New Towns across Britain, the design of public buildings like hospitals and schools, as well as the establishment of official organizations dedicated to promoting the benefits of design - like the Council of Industrial Design - the postwar state took a deliberate hand in shaping what Ben Highmore calls 'the designed environment' of postwar Britain (Highmore 2009: xiii).

Street furniture was just one category of design in which the postwar state became involved. From a position of some remove, the state's interest in this area can be seen in light of the view promoted by the President of Board of Trade in 1944, Hugh Dalton, that encouraging higher standards in design would improve the daily lives of 'ordinary men and women' and rebuild Britain's export trade (MacCarthy 1979: 73-74). In a practical sense however, the state's interest in street furniture can be attributed to the considerable damage inflicted upon Britain's built environment during wartime. Much of Britain's street furniture needed to be replaced, but the question was how?

For some organizations, the devastation of the Blitz provided 'the exceptional opportunity of starting from scratch' (the Royal Fine Art Commission 1949: 5); while for others, the threat posed by modern development was potentially just as destructive. As a result of this tension, the question of what street furniture should look like and the effect it should have on its surroundings became particularly divisive. Modern lampposts for instance, were disliked for looking out of place in winding country lanes or for their seemingly oppressive height (Betjeman 1953: 6). Their glare was criticized for its impact on courting couples and women's make-up, or the sleeping habits of those nearby (Ritson 1953). Bus shelters were derided for looking too 'self-conscious' (Russell 1958: 5) and litterbins for looking too 'genteel' (the Architectural Review 1952: 59). And yet, while this debate was outwardly concerned with the style of such objects, in fact street furniture emerged as a forum through which postwar anxieties about taste, class, and power could be discussed. Such anxieties were particularly relevant for postwar Britain, given the unprecedented influence the government had over design decisions, but which simultaneously witnessed an increase in voices participating in discussions about the role of the state. In such a context, the question of who has the authority to make design decisions on behalf of others, and the manner in which those decisions are made, becomes critical.

The following paper will look at the state's use of design as a means of giving physical expression to a social, political and cultural agenda. It focuses on the state in postwar Britain, and its participation in a series of street furniture projects initiated between the mid-1950s and the late 1960s, namely Kenneth Grange's 1958 parking meter design, Jock Kinneir and Margaret Calvert's road signage developed between 1957-64 and David Mellor's 1966 design for a letterbox. By addressing these examples, this paper shows that reading the banal built world can expand our knowledge of how political power works, and that historical case studies have relevance for current debates about the designed environment. 


\section{Main text}

While Winston Churchill's coalition government led Britain out of the Second World War, the results of the General Election in 1945 illustrated the very different hopes and aspirations of British people for peacetime. Clement Attlee's Labour Party defeated Churchill that year by a landslide majority, and would go on to radically change the country and the role of government. Yet the postwar state was not only concerned with social and economic policy; it was also committed to improving the standards of people's lives through design. The design of housing, transport, domestic and consumer goods, as well as objects that furnished the street, were all affected by the government's attempt to rebuild the social order and introduce an appreciation for better design into people's everyday lives. There are several important examples where the government was involved in the design of street furniture during the late 1950s-1960s, and because of the scale of these projects, they made an enormous contribution to the appearance of Britain. One of the earliest of these design interventions concerns the parking meter.

The parking meter's route into British consciousness began with a pilot scheme in 1956 approved by senior members of Parliament, including Prime Minister Winston Churchill, Anthony Eden and Harold MacMillan. The Council of Industrial Design considered existing American parking meter designs unacceptable for the British streetscape, and the organization played a key role in commissioning industrial designer Kenneth Grange to design a more appropriate model. Grange's 1958 design (see fig.1) was, according to architectural writer Deyan Sudjic, 'a smooth, suave, sand dune of an object' (Sudjic 2011: 18). While some questioned the extent to which the central objective of the parking meter design concerned a 'pleasing outward appearance', Grange rejects this interpretation (the Municipal Journal 1962: 1740). For him, style was important only insofar as it supported his desire to give the public what he felt deserved, namely 'to join the modern world' (Grange 2012). The notion that the British public deserved modern design aligns with a point made by design historian Penny Sparke, for whom Grange's work exhibits a 'life-long commitment to modernism', within which was 'the idea that mass production has the capacity to bring "good design" within the reach of everyone' (Sparke 2011: 101). In this way, design can be understood in light of the social policies of the period.

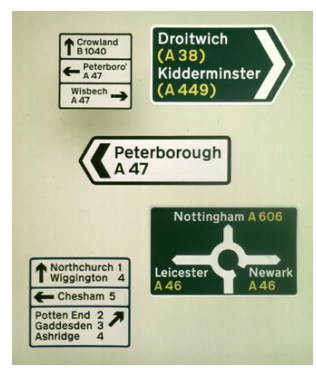

Figure 2.

Traffic signs designed by Jock Kinneir and Margaret Calvert, 1957-64

Yet the social optimism represented by Grange's parking meter design was slowly replaced by an expectation that design should be rational above all else, and that moral judgments on what the public deserved were merely the expressions of an elitist cultural establishment. The government-initiated traffic signage project at the end of the 1950 s illustrates this shift. 
theme 5

society

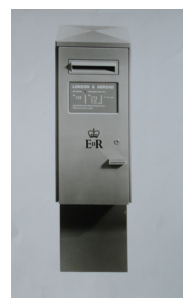

Figure 3. F-Type Letterbox designed by David Mellor for GPO, 1966 strand 1

design policies

In 1957 the Ministry of Transport established the Advisory Committee on Traffic Signs for Motorways, known as the Anderson committee after its chairman Sir Colin Anderson. According to Phil Baines, a writer on graphic design, the objective of the Anderson committee was to address the problem of signage for the Preston bypass on the London to Yorkshire motorway then under construction (Baines and Dixon 2008: 24). Graphic designer Jock Kinneir was appointed as design consultant for the project, in partnership with his former student Margaret Calvert. In an interview with Calvert, she claimed that the appearance of the signs (see fig.2) was primarily about legibility, in which design mannerisms were deliberately avoided, and the lettering was complementary, i.e. 'there quietly but not the main story' (Calvert 2013). And yet as much as Kinneir and Calvert were responsible for design, the MoT had a preference for how the signs should look. Calvert recounts how one committee member impressed upon Kinneir his preference that the signs ought to be 'as dark as old dinner jackets', despite the fact that Kinneir wished them to be lighter in tone (ibid.). Moreover, even though the system scored badly in readability tests, it was later extended to the entire British road network because it conformed to the government's preference for modern design.

The impact of the government's interest in modern design was also extended to Britain's postal service. In 1966 industrial designer David Mellor was commissioned by the General Post Office to design a new letterbox for the country. Postmaster-General Anthony Wedgwood Benn (better known as the late Tony Benn) believed that Gilbert Scott's original design from 1879 could be improved (MacCarthy 1966). As Labour minister and a modernizer, Benn argued in 1964 that 'the most distinguishing characteristic of a vigorous society is one in which the future is more real and important than the past' (Glendinning 2013). And in the context of the letterbox, he would put this argument into practice. Benn's opinion was that a rectangular design would be much better for holding square letters, and would, in turn, bring the organization into line with other nationwide attempts to modernize.

Yet attempts to impose a modern style of street furniture upon Britain prompted considerable public criticism, and Mellor's F-type letterbox was no exception. As predicted by design historian Fiona MacCarthy (and also Mellor's wife) the new box made 'a lot of enemies: enemies of progress, imbibers of nostalgia; men who shudder at the Council of Industrial Design' (MacCarthy 1966). While the efficiency of the new design was not disputed - it reduced collection time by half - nevertheless, some argued that it looked too 'teutonic' (RFAC n.d.), while others argued that its sharp edges posed a hazard for drunks (Sheffield Galleries and Museums Trust 1998: 57). Following eight years of development, only 205 F-type letterboxes were ever produced. Whether this was the result of public criticism is unclear, but like Grange, Kinneir and Calvert, Mellor considered such projects to be 'an important opportunity for changing the visual culture of the country as a whole' (ibid: 30 )

\section{Conclusion}

This material is significant for several reasons. In a discursive sense, it shows that the reasoning used to justify postwar street furniture design changed considerably during a period of equally significant social and political transition. While Kenneth Grange spoke of his belief that the British public were entitled to 'good design' - a sentiment wholeheartedly supported by the government and the state-funded CoID - both Jock Kinneir and Margaret Calvert's signage system and David Mellor's F-type letterbox turned on ideas of rationality, without seeking to impose moral judgments upon British society. 
However, the material also shows that successive postwar governments were in fact conscious of style, and its potential to support a broader political agenda. These agendas were initially framed by social policy and ideas linked to the Welfare State, and gradually evolved to accommodate modernization and efficiency. We can say then, that over the course of the postwar period, the government clearly sought to influence the design of street furniture, as part of its commitment to reshaping the social order of the country. The design of street furniture was considered important because it could be used to project official values into public space, signaling the transition in ideological occupancy.

I believe that the historical case studies discussed in this paper remain relevant within current debates about the designed environment. Though government is no longer as heavily involved in the street furniture industry as it was during the postwar period, nevertheless, political power continues to shape the designed environment.

\section{References}

\section{Secondary sources:}

Phil Baines, Catherine Dixon, Signs: Lettering in the Environment, (London: Laurence King, 2008. First published in 2003);

Ben Highmore, The Design Cultures Reader, (Abingdon, Oxon: Routledge,2009); Miles Glendinning, The Conservation Movement: A History of Architectural Preservation, (London: Routledge, 2013);

Penny Sparke, 'Modern Objects for Personal and Domestic use', in Kenneth Grange: Making Britain Modern, (London: Design Museum and Black Dog Publishing, 2011); Deyan Sudjic, 'A Modernist at Heart', in Kenneth Grange: Making Britain Modern, (London: Design Museum and Black Dog Publishing, 2011).

\section{Newspapers and periodicals:}

John Betjeman, Letters Page, Design, No.55, July 1953;

Design, No.63, March 1954;

Fiona MacCarthy, 'Post Taste', the Guardian, 5th February 1966;

The Municipal Journal, 8th June 1962, Vol.70, p.1740;

'Lettering', the Architectural Review, January 1952, Vol.111, No.661, p.59.

\section{Interviews:}

Interview with Kenneth Grange, London 21st November 2012;

Interview with Margaret Calvert, London 4th July 2013.

\section{Archival material:}

Letter to Mr. Bainbridge from N. Ritson, Highgate 14th August 1953, loose in 'Street Lighting: General Questions and Correspondence on Design Amenity and Aesthetics', N.A. Cat. Ref.: HLG 51/847;

'Road Traffic Bill: Parking Meters', Memo by the Minister of Transport and Civil Aviation, 26th November 1954, N.A. Cat. Ref.: CAB 129/72 0011, p.1; 'Pillar Box: Proposed New Design', N.A. Cat. Ref.: BP 2/126; Gordon Russell, 'Civic Design in the Streets', loose in 'Discussions on the Design of Street Furniture', N.A. Cat. Ref.: BP 2/279;

The Royal Fine Art Commission, 'Design of Street Furniture', Point 26.8, 7th October 1949, p.5, loose in 'Design: Correspondence and Minutes', N.A. Cat. Ref.: BP 2/127. 
